\title{
ANALISIS PENGARUH WAKTU DAN JARAK PERJALANAN KAPAL TERHADAP BIAYA LOW SULPHUR SURCHARGE
}

\section{AN ANALYSIS OF THE EFFECT OF SHIP VOYAGE TIME AND DISTANCE ON LOW SULPHUR SURCHARGE}

\author{
Gita Kurnia*1, Maulida Nawadir ${ }^{2}$ \\ ${ }^{1,2)}$ Program Studi Teknik Logistik, Universitas Pertamina, Jakarta Selatan, 12220, Indonesia
}

\begin{tabular}{|c|c|}
\hline ARTICLE INFORMATION & A B S T R A C T \\
\hline $\begin{array}{l}\text { Article history: } \\
\text { Received: Juli, 05, 2021 } \\
\text { Revised: September, 30, } 2021 \\
\text { Accepted: Oktober, 29, } 2021\end{array}$ & $\begin{array}{l}\text { The danger of ship emission caused by HFO (Heavy Fuel Oil) fuel type has } \\
\text { become a serious matter due to its high containment of sulphur as much } \\
\text { as } 3.50 \% \mathrm{~m} / \mathrm{m} \text {. The IMO (International Maritime Organization) took action } \\
\text { on this problem by releasing a new regulation to limit sulphur in the ship } \\
\text { fuel as low as } 0.50 \% \mathrm{~m} / \mathrm{m} \text {. This regulation leads to an additional tariff called } \\
\text { the LSS (Low Sulphur Surcharge). As an impact, shipping companies } \\
\text { charge this fee to customers and ocean freight forwarders. Hence there is }\end{array}$ \\
\hline $\begin{array}{l}\text { Keywords: } \\
\text { Low Sulphur Surcharge } \\
\text { Multiple Linear Regression } \\
\text { Freight Cost } \\
\text { Shipping } \\
\text { Ocean Freight Forwarder }\end{array}$ & $\begin{array}{l}\text { determining the LSS charge amount is unknown, so it is still uninformative } \\
\text { for the public and academic fields. This study aims to analyse which } \\
\text { variable gives the most influence on the amount of the LSS tariff by using } \\
\text { the multiple linear regression method. The study finds that the shipping } \\
\text { distance variable is the dominant variable with a contribution value of } \\
86.48 \% \text { and has a positive relationship with the LSS tariff. On the other } \\
\text { hand, though the voyage time also influences the tariff, the effect is weaker } \\
\text { and shows a negative relationship with the LSS tariff. The additional } \\
\text { calculation of polynomial regression also indicates a similar result, where } \\
\text { shipping distance influences dominantly and positively against the LSS } \\
\text { tariff. }\end{array}$ \\
\hline
\end{tabular}

*Corresponding Author

This is an open access article under the $\underline{\mathrm{CC}-\mathrm{BY}}$ license.

Gita Kurnia

Email:

gita.kurnia@universitaspertamina.ac.id

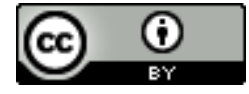

\section{INTRODUCTION}

The use of ship transportation mode is currently the primary choice for global trade, as it transports up to $90 \%$ of traded goods across the ocean. Sea transportation is also an attractive choice for customers, due to the large ship capacity, wide range distribution that can reach small islands, ability to carry various types of goods either containerized, general cargo, dangerous goods and others, relatively cheap shipping rates and environmentally friendly modes [1]. Sea transportation also holds a vital role in cargo distribution in Indonesia, an archipelagic country with approximately two-thirds of it is the sea area [2].

Over time, as more new ships are built and deployed by the shipping companies, more emissions are generated from the ships' fuel. The standard type of fuel used by ships is HFO (Heavy Fuel Oil). HFO is a fuel consisting of a wide range of oils, ranging from distilled oils to residual oils, which must be heated to $260^{\circ} \mathrm{C}$ or higher before they can be used. In general, HFO consists of residual oil mixed with distillation to meet particular needs. HFO is commonly referred to as bunker oil [3]. The International Maritime Organization (IMO) 
states that when engine combustion occurs, ship produces emissions due to the sulphur content in the HFO [4]. Towards the environmental protection from the danger of sulphur emission, IMO added a new regulation related to shipping fuel and emission called IMO 2020, which came into force on January 1, 2020. Indonesian Ministry of Transportation also supports this regulation by publishing a Circular Letter no. 35/2019 about "Obligation to use low sulphur fuel and prohibition of transporting or carrying fuel that does not meet the requirements and waste management of exhaust gas recirculation from ships" [5].

IMO 2020 describes that the sulphur limit in fuel oil used by ships operating outside the designated emission control area is reduced to $0.50 \% \mathrm{~m} / \mathrm{m}$ (mass per mass), better known as low sulphur fuel. This regulation will significantly reduce the amount of sulphur oxide derived from ships. It will provide significant health and environmental benefits to the world, especially for populations living near ports and coastal areas.

The new regulation also states that it is mandatory for all shipping voyages in the world to use low sulphur fuel. However, it will increase the associated fuel and equipment costs for the shipping companies [6] because low sulphur emission fuels are highly filtered, thus being more expensive by up to four times than regular fuels [7]. Mega shipping companies such as Maersk Line also stated that the extra fuel costs might exceed USD 2 billion to comply with the new regulation [8]. As a result, higher fuel costs simultaneously will increase the freight rates. Refer to an earlier prediction by Notteboom [9], the use of low sulphur fuel is expected to increase transport prices. He demonstrated the impact of the low sulphur agreement on freight rates within the context of short sea shipping in Northern Europe. An increase in the shipping cost caused by the use of low sulphur fuel implementation also has been validated in the recent study by Shuaibu [10] under the research title "The economic impact of low sulphur compliance on future fuel cost and container freight rates: a case study of ShanghaiLagos". The research examined the potential economic impact of new IMO regulations on shipping liner companies in Nigeria, emphasising container freight rates and future fuel costs. The research generates an estimation of a $15-25 \%$ increase in freight rates in Nigeria, and fuel costs will be more expensive considering that based on the survey, shipowners preferred to use low sulphur fuel.
Though many maritime players fear the increasing freight cost, research conducted by Rahm [11] under the research title "The Costly Future of Green Shipping" revealed that promoting the regulation on reducing sulphur oxide emission have been implemented in the company's business strategy and will be a competitive advantage for the shipping companies. Another study by Sys et al. [12] also examines the potential impact of international emission regulations maritime world in economies specific to Northern European and Southern Europe ports. The study result claims that international laws related to emissions do not affect the economy at the port. The use of low sulphur fuel in compliance with the IMO policy also was proven as an appropriate option for long term use, according to a costbenefit analysis conducted by Wu and Lin [13]. However, this study has not yet considered parameters such as shipping routes, ship types and age.

Furthermore, shipping companies formed strategies to meet the IMO low sulphur fuel requirements while at the same time protecting the environment and pressing the costs incurred. As fuel cost can spend more than $60 \%$ of ship operating cost [14], the higher low sulphur fuel cost threatens to be a severe concern for them [15]. To cope with these expensive costs, shipping companies followed each other's footsteps by announcing an additional tariff called the Low Sulphur Surcharge (LSS). This additional tariff is charged to the users of the shipping voyage, one of which is the ocean freight forwarders, who then charge this price to their customers. The tariff may already be included in the service charge or presented as an additional service. It can be concluded that the increase of the ship operating cost is being passed to the shoulders of the consumers by increasing the prices of transported cargoes [16].

As a response, the existence of LSS as an additional surcharge was greeted with wariness from shippers worldwide [17]. A similar situation was found in Indonesia. Some complaints were raised due to the emergence of the LSS tariff. The tariff charged by shipping lines was deemed too expensive and too various, which caused many complaints from container logistics companies because their customers were hesitant to send cargoes by ship. The tariff range can vary from Rp400,000.00 to Rp1,000,000.00 per container, depending on its destination. There are also no exact details and rules on determining the cost component structure [18]. A Senior Consultant of 
Supply Chain Indonesia, through an interview with a maritime website, also expressed his regret of the lack of transparency and negotiation space from the shipping line side regarding LSS tariff, and there has been no explanation regarding the price difference imposed by the freight forwarders [19]. The lack of information given to customers regarding the tariff structure is feared to create hesitance and a sense of customer distrust.

If summarized, previous studies stated that low sulphur fuel usages onboard ships are advantageous and not economically detrimental. Rahm [11] concluded that promoting the lowsulphur regulation will be a company competitive advantage. At the same time, Wu and Lin found [13] that low sulphur usage will benefit the company in the long term with cost consideration. Sys et al. [12] also ensured that the port economy would not suffer because of this new, more expensive, low sulphur fuel. However, Indonesian container logistics companies voiced their concerns that implementing the low sulphur fuel forced them to pay higher freight rates due to the additional LSS tariff [18]. Their problem is with reason, as a study by Notteboom [9] and Shuaibu [10] predicted that freight rates would increase due to the implementation of low sulphur fuel. The Indonesian container logistics companies also claimed that the LSS has no exact information on its cost structure and is too various and expensive $[18,19]$. Therefore, a determination of the dominant factors which influence the LSS tariff is necessary to conduct. Several studies have identified the benefit of low sulphur fuel, and its impacts on freight rates increase. This research also focuses on one of the impacts of the lowsulphur fuel regulation: the emergence of the LSS tariff. However, no previous studies have analysed the LSS itself nor the determinant effect of the LSS tariff. Thus, this research aims to fill this research gap.

This research examines which factors dominantly influence the amount of LSS tariff by applying multiple linear regression. This study focuses on LSS tariff as the dependent variable, which then being examined of its relationship with the independent variables. The authors received data and information from a logistics company in Surabaya, Indonesia, namely PT Global Putra Indologistics (GPI), to identify the independent factors.

At first, one of the authors conducted an internship in this company as sales support. She was assigned a task to determine the factors influencing the LSS tariff because the company had not done the analysis before. Moreover, this company is relevant as the case study object of the paper because GPI is a freight forwarding company, one of the industries affected by the existence of LSS [16]. As mentioned before, shippers in Indonesia expressed their concerns regarding the lack of information on the LSS tariff structure and price difference imposed by the freight forwarders [19]. Their situation is likely because forwarding services are growing and needed by the industries that must ship their cargo by sea. Statistically, around $93 \%$ of customer companies use third-party sea freight forwarding services [20]. In Indonesia, freight forwarding was grown $11,8 \%$ in the five-year range from 20132017, with ocean freight forwarding as the significant contributor [21]. Also, in the first semester of 2020, there were an increase in ALFI (Indonesian Logistics and Forwarders Association) members who upgraded their domestic service class to international class [22]. This elaboration means that forwarding services are greatly needed and continuously growing. The LSS tariff is also unavoidable because the tariff is charged to them by their shipping lines clients. As a forwarding company, GPI engages in e-logistics, low-cost shipping and freighter service, commercial logistics, energy logistics, project logistics, trading and supply chain management. In carrying out their domestic sea network activities, GPI cooperates with two shipping companies that provide sea transportation services. As the new IMO regulation comes into force, those shipping companies charge GPI with the additional LSS tariff, who then forwards this charge to their customer's accounts. The tariff is charged to the customers and listed in the SO (Sales Order) of the shipping expedition activities.

The selection of independent variables which influence the LSS tariff was done in three ways, initial observation, interview with shipping company representatives, and literature study. First, based on initial observation by authors at GPI, we found several questionable invoices which state inconstant LSS tariff. For example, several shipping voyages had different LSS tariffs rates for the same routes, and several had similar tariffs even though the sailing time was longer. The tariff ranged from $\mathrm{Rp} 400,000.00$ to Rp1,200,000.00 per container. The tariff structure was not informed by the shipping companies as the clients of GPI. The shipping companies passed this tariff amount to GPI, and GPI added it to their customer's invoices. This system raised an initial question, whether sailing time or sailing distance influence the amount of the LSS tariff. Therefore, to validate these data and find the 
answer to the initial question, the authors conducted the second step: interview.

The interview was carried out to 2 respondents from different shipping companies as the clients of GPI. The respondents were questioned about how the LSS fee amount was determined at each shipping company, respectively. The respondent from the shipping company, namely PT XYZ, stated that his company set the LSS fees mainly based on the length of time of ship voyage. The second respondent from the shipping company PT $A B C$, gave a different opinion. This company set the LSS fees based on the distance of the ship voyage as the main calculation. Therefore, the authors collected similar candidates of independent variables from the interview result and the initial observation question on step one: the ship voyage time and shipping distance.

Third, the authors performed further literature reviews to confirm the independent variables. The study by Bialystocki [23] explains that shipping voyage is related to fuel consumption, and the elements of fuel consumption cost include time and distance of the ship voyage. As LSS compensate for the expensive low sulphur fuel cost, ship voyage time and distance are relevant to be considered. Bui-Duy et al. [24] argue in their research that higher velocity leads to higher fuel consumption and affects sailing time. Andersson et al. [25] presented that in planning the ship voyage, speed optimization (and voyage time) is best obtained if integrated with the planning of shipping routes. In their literature review, Zis et al. [26] summarized that the key to achieving the company competitiveness is to balance the shipping cost and increased sailing time. Furthermore, several shipping companies and forwarding companies mentioned their LSS price range base. CNC, a shipping company part of CMA CGM Group, sets the LSS tariff based on the short and long-distance of the ship voyage [27]. Maersk's Far East Asia to Mediterranean scope includes the LSS in the container shipping rates, based on shipping distance [28]. Bacargo, a freight forwarding company in Indonesia, sets the LSS tariff based on the distance from the Port of Origin to the Port of Destination [29]. Adding from the interview result, $\mathrm{PT} X Y Z$ sets the LSS tariff mainly based on ship voyage time, while $P T A B C$ sets the tariff based on ship voyage distance. After gathering information from both literature study and interview results, the authors selected the independent variables to be further utilized in this research, namely ship voyage time and distance.
Hopefully, this study will significantly give several benefits to the maritime shipping industry while supporting the smooth implementation of the sulphur regulation of IMO. The findings of this study will provide valuable insights into individual shipping lines and freight forwarders to create shipping strategies. The greater demand for shipping justifies the unavoidable LSS cost. Identifying the most significant value may help the shipping companies design strategies in designing the voyage pattern and sailing duration with minimum shipping cost. The findings may also provide valuable insights for cargo owners to choose suitable and cheaper available routes. For the researchers, this study will uncover the dominant variables of LSS, which have never been discussed before in any research and provides room for improvement for further studies. Despite the expected significance of the study, this research has some limitations, as it only includes the main parameters of ship voyage time and distance. Various conditions such as weather and the load of the cargo are excluded.

\section{RESEARCH METHOD}

Based on the research problem, this type of research is quantitative research. Quantitative research is a process of finding knowledge using data in the form of numbers as a tool to analyse information about what it is required to know [30]. This study is designed to determine the dominant variable that affects the amount of the LSS tariff by using multiple regression analysis. Assuming that the data was linear, multiple linear regression was chosen because it would mathematically represent how shipping time and distance variables influence the amount of LSS tariff. With mathematical results, it would be constructive to analyse the cause. Moreover, to add the complexity of this research, the authors also conducted a polynomial regression to compare the variables' relationship results with the multiple linear regression. Polynomial regression was added because polynomial may provide a greater explanatory than traditional regression. After all, it provides nuanced views on the relationships between different combinations of independent variables and a dependent variable in threedimensional space [31].

In the previous section, the background of the problem, the explanation of the variable selection process, the research objective, and contributions have been thoroughly discussed. Furthermore, the paper proceeds in the following manner. This section provides an overview of multiple linear 
regression tests and the research hypothesis. The step-by-step process of the multiple linear regression tests and result analysis are explained in the results and discussion section. Therein, the polynomial regression result is also presented. Finally, the paper summarizes the results and its future improvement for the subsequent research.

Multiple linear regression test calculation methods were utilized using SPSS version 24 software to conduct data analysis and processing. Linear regression tests were used to see how both independent variables, namely ship voyage time and shipping distance, affect the amount of LSS tariff (dependent variable). A study by Lai et al. tested hypotheses to investigate the relationship between internal tariff rates, international trade, and transport logistics development in ASEAN countries, using a simple regression calculation [32]. According to Pandis et al., in linear regression, one can conclude more parameters to find factors that predict a result better [33]. This analysis is called multiple linear regression. This regression analysis method will help explain the relationship between two variables (variables) or more, especially between variables containing cause and effect [34]. The research also references its method from a previous study by Aisyah and Kuswantoro, who utilized multiple linear regression to determine the relationships of Gross Domestic Products, CPO (Crude Palm Oil) price and currency value of partner countries on Indonesia's CPO export numbers [35]. Moreover, Wulandari and Zuhri determined the links of Indonesia's investment and net export on the country's economic growth by using multiple linear regression [36].

The regression calculation process goes through several classical assumption tests to produce an equation with Best Linear Unbiased Estimation (BLUE). Hence, using the multiple linear regression method can explain the relationship that is close to the original data, valid, and feasible to use [37]. The classic assumption tests are normality, heteroscedasticity, multicollinearity, linearity, and autocorrelation. In addition, there are also model feasibility tests such as model feasibility test (F-test), regression feasibility test (ttest), determination coefficients, and model interpretations.

As the object of this research, secondary data from GPI was collected. The analysed LSS tariff was only collected from the voyages using one shipping company client, namely PT XYZ, because this company provides approximately
$50 \%$ of the ship transportation services for GPI. The samples used in this study are the shipping services data provided by PT XYZ from July 24 to August 24, 2020. The reason for choosing this time range is because it is according to the duration of authors registered and performed the field research at the company.

This research develops hypotheses to support the research question. A hypothesis is a tentative sentence that states the relationship between two or more variables [38]. In the previous section, the process of selecting the independent variables was already discussed. Thus, based on literature reviews and the initial interview results with the shipping companies' representatives (PT XYZ and PT $A B C$ ) regarding how the LSS tariff is determined, this research formulates the following hypothesis to show the relationship between the independent and the dependent variables.

Hypothesis $1(\mathrm{H} 1)$ :

- Ship voyage time has a positive influence on the determination of the LSS tariff rates

Hypothesis $2(\mathrm{H} 2)$ :

- Ship voyage distance has a positive influence on the determination of the LSS tariff rates

Table 1. Kolmogorov-Smirnov test

\begin{tabular}{lccc}
\multicolumn{1}{c}{ Variable } & Statistic & df & Sig. \\
\hline Time & 0.240 & 370 & 0.000 \\
Distance & 0.210 & 370 & 0.000 \\
LSS & 0.376 & 370 & 0.000 \\
\hline
\end{tabular}

\section{RESULT AND DISCUSSION}

\subsection{Normality Test}

Well-known normality tests include the Kolmogorov-Smirnov test and Shapiro-Wilk test. Both tests generate normal distribution results if the significance value is $>0.05$. The KolmogorovSmirnov test is carried out when the sample size is more than 50 . On the other hand, a smaller sample size (less than 50) may use the ShapiroWilk test to test the normality. This research used 370 data samples; therefore, the KolmogorovSmirnov test was conducted.

Based on the calculation results in Table 1, the data did not meet the requirement for normal distribution because the significance value is less than 0.05 . The 370 data in this study were also tested using box plots where outliers did not occur. The authors then used a rule of thumb that assumed parametric tests like regression could 
also be used, even though the data are not normally distributed. This assumption is based on considerations that parametric statistics like regression will yield correct answers even with non-normal distributions, with no fear of coming to the wrong conclusion [39]. Other considerations are that not all research data can be normally distributed [40]. Moreover, even with a significance value fixed to 0.05 , a sufficient number of samples are required to predict the normality test's reliability better [41]. Subsequently, the authors performed a data adequacy test. This test aims to ensure that the number of samples exceeds the number of theoretically calculated samples. Thus, the 370 data can describe the population well.

Data adequacy testing was conducted using the following equation:

$$
N^{\prime}=\left[\frac{\frac{k}{5} \sqrt{N \sum x^{2}-\left(\sum x\right)^{2}}}{\sum x}\right]^{2}
$$

$\mathrm{k}=$ Confidence level $(99 \% \approx 3,95 \% \approx 2)$

$\mathrm{s}=$ Degree of precision

$\mathrm{N}=$ Number of observation data

$\mathrm{N}^{\prime}=$ Theoretical amount of data

$\mathrm{x}=$ Observation data

If $\mathrm{N}^{\prime} \leq \mathrm{N}$, then the data is considered sufficient, but if $\mathrm{N}^{\prime}>\mathrm{N}$ data is not enough, it is necessary to add data. From the formula of data adequacy calculation, data can be calculated using ship voyage time data as $\mathrm{x}$. The results are as follows:

$\mathrm{k}=95 \% \approx 2$

$\mathrm{s} \quad=10 \% \approx 0.01$

$\mathrm{N}=370$

$\sum \mathrm{x}^{2}=5088$ (using the amount of ship voyage time data)

$\left(\sum \mathrm{x}\right)^{2}=1537600$

$\sum \mathrm{x}=1240$

$N^{\prime}=\left[\frac{\frac{2}{0.01} \sqrt{370 \times 5088-1537600}}{1240}\right]^{2}=89.7399$
The calculation generates that $\mathrm{N}^{\prime}$ is smaller than $\mathrm{N}$ $(89.7399<370)$, and we conclude that the data is sufficient to perform multiple linear regression processes.

\subsection{Heteroscedasticity Test}

Table 2. Heteroscedasticity test output

\begin{tabular}{lrr}
\multicolumn{1}{c}{ Variable } & \multicolumn{1}{c}{ t } & \multicolumn{1}{c}{ Sig. } \\
\hline (Constant) & 6.226 & 0 \\
Time & 0.843 & 0.4 \\
Distance & -1.235 & 0.218 \\
\hline
\end{tabular}

The heteroscedasticity test aims to test whether there is a variant and residual inequality from one observation to another in the regression model [42]. A good regression model is if a variant of one residual observation to another observation remains or homoscedasticity (Significant value > 0.01). Table 2 describes the result of the heteroscedasticity test, which shows that the significance (Sig.) value for the shipping time variable is 0.400 and for the shipping distance variable is 0.218 . The result concludes that the significance values of both variables indicate no symptoms of heteroscedasticity.

Table 4. Multicollinearity test

\begin{tabular}{|c|c|c|c|c|}
\hline Variable & $t$ & Sig. & $\begin{array}{r}\text { Colline } \\
\text { Statis } \\
\text { Tolerance }\end{array}$ & VIF \\
\hline (Constant) & 17.786 & 0 & & \\
\hline Time & -3.662 & 0 & 0.634 & 1.578 \\
\hline Distance & 34.11 & 0 & 0.634 & 1.578 \\
\hline
\end{tabular}

\subsection{Multicollinearity Test}

Multicollinearity test is intended to test whether there is a high or perfect correlation between independent variables in the regression model [43]. The test results are visible in Table 3. It shows the VIF value for each variable is 1.578 $(<10)$, and the Tolerance value of $0.634(>0.10)$ which means that there is no multicollinearity in the regression model. In the absence of

Table 3. Linearity test

\begin{tabular}{|c|c|c|c|c|c|c|c|}
\hline 2 & $=$ & & $\begin{array}{c}\text { Sum of } \\
\text { Squares }\end{array}$ & df & $\begin{array}{l}\text { Mean } \\
\text { Square }\end{array}$ & $\mathbf{F}$ & Sig. \\
\hline \multirow{4}{*}{$\begin{array}{l}\text { LSS * } \\
\text { time }\end{array}$} & & (Combined) & $1.1243 \mathrm{E}+13$ & 6 & $1.874 \mathrm{E}+12$ & 74.902 & 0 \\
\hline & Between & Linearity & 4.66149E+12 & 1 & $4.661 \mathrm{E}+12$ & 186.33 & 0 \\
\hline & Groups & $\begin{array}{l}\text { Deviation } \\
\text { from }\end{array}$ & $6.58154 \mathrm{E}+12$ & 5 & $1.316 \mathrm{E}+12$ & 52.616 & 0 \\
\hline & \multicolumn{2}{|c|}{$\begin{array}{c}\text { Within Groups } \\
\text { Total }\end{array}$} & $\begin{array}{r}9.0813 \mathrm{E}+12 \\
2.03243 \mathrm{E}+13\end{array}$ & $\begin{array}{l}363 \\
369\end{array}$ & $2.502 \mathrm{E}+10$ & & \\
\hline
\end{tabular}


Table 5. Autocorrelation test

\begin{tabular}{|c|c|c|c|c|c|}
\hline \multirow[b]{2}{*}{ Model } & \multirow[b]{2}{*}{$\mathbf{R}$} & \multicolumn{2}{|c|}{ Model Summary } & \multirow[b]{2}{*}{$\begin{array}{l}\text { Std. Error of } \\
\text { the Estimate }\end{array}$} & \multirow[b]{2}{*}{$\begin{array}{l}\text { Durbin- } \\
\text { Watson }\end{array}$} \\
\hline & & $R$ squared & $\begin{array}{l}\text { Adjusted R } \\
\text { squared }\end{array}$ & & \\
\hline 1 & .955 & 0.913 & 0.912 & 27254.17621 & 1.906 \\
\hline
\end{tabular}

Table 6. Model feasibility test (f-test)

\begin{tabular}{ccccccc}
\hline Model & & $\begin{array}{c}\text { Sum of } \\
\text { Squares }\end{array}$ & df & Mean Square & F & Sig. \\
\hline \multirow{2}{*}{1} & Regression & $1.65686 \mathrm{E}+13$ & 2 & $8.28429 \mathrm{E}+12$ & 809.513 & $.000^{\mathrm{b}}$ \\
& Residual & $3.75575 \mathrm{E}+12$ & 367 & 10233661640 & & \\
& Total & $2.03243 \mathrm{E}+13$ & 369 & & & \\
\hline
\end{tabular}

a Dependent Variable: LSS

b Predictors: (Constant), distance, time

multicollinearity, we conclude that there is no correlation between the independent variables.

\subsection{Linearity Test}

A linearity test is conducted to confirm a linear relationship between independent and dependent variables [44]. From the Anova result in Table 4, it can be seen that the value of Sig. deviation from linearity is 0.00 . This confirms that the value is less than 0.05 , therefore it can be concluded that there is a linear relationship between independent variables and dependent variables.

\subsection{Autocorrelation Test}

The autocorrelation test aims to test whether there is a correlation between residuals in the $t$ period with the $\mathrm{t}-1$ period (earlier) in a linear regression model [45]. A good regression model is a regression that is free from autocorrelation. Table 5 summarizes the output of the autocorrelation test results. The table shows that the $d$ (DurbinWatson) value is 1.906. A calculation for correlation determination was carried out using the Durbin-Watson table to identify whether the $d$ value is within the range of $\mathrm{Du}$ and $4-\mathrm{dU}$, as follows:

$\mathrm{dU}<\mathrm{d}<4-\mathrm{dU}$

$1.83483<1.906<4-1.83483$

$1.83483<1.906<2.16517$

From this calculation result, the $d$ value is shown to be greater than $\mathrm{dU}$, and smaller than $4-\mathrm{dU}$.
Therefore, it can be concluded that there is no problem or symptom of autocorrelation.

\subsection{Model Feasibility Test (F-Test)}

The F-test is the initial stage of identifying whether a regression model is feasible or not [46]. If the test result shows that the significance value is smaller than 0.05 , the recommended regression model is feasible. On the contrary, if the value is greater than 0.05 , the model is deemed not feasible. Based on the test result in Table 6 , the significance value is $0.000<0.05$, the regression model is feasible for use.

\subsection{Regression Feasibility Test (t-Test)}

The t-test is a partial regression coefficient test that partially determines the significance of the role between the independent variables on the dependent variable by assuming that other independent variables are considered constant. [47]. If the significance value is smaller than 0.05 or (otherwise predetermined), it means that the independent variable has a significant effect on the dependent variable. Contrarily, if the significance value is greater than 0.05 , then the independent variable has no significant effect on the dependent variable.

Table 7 describes the output of the t-test. The significance value shows smaller than $0.05(0<$ 0.05 ), which means that there is an influence of

Table 7. Regression feasibility test (t-test)

\begin{tabular}{llrrrrr}
\multicolumn{8}{c}{ Coefficients } \\
\hline \multirow{2}{*}{ Model } & \multicolumn{2}{c}{$\begin{array}{c}\text { Unstandardized } \\
\text { Coefficients } \\
\text { B }\end{array}$} & \multicolumn{1}{c}{$\begin{array}{c}\text { Standardized } \\
\text { Coefficients } \\
\text { Beta }\end{array}$} & t Error & & Sig. \\
\hline \multirow{2}{*}{1} & (Constant) & 305349.086 & 17167.811 & & 17.786 & 0 \\
& time & -15242.442 & 4162.45 & -0.103 & -3.662 & 0 \\
& distance & 886.212 & 25.981 & 0.962 & 34.11 & 0 \\
\hline
\end{tabular}

a Dependent Variable: LSS 
Table 8. R-Value model summary

\begin{tabular}{cccc} 
Model & $\mathbf{R}$ & $\begin{array}{c}\mathbf{R} \\
\text { squared }\end{array}$ & $\begin{array}{c}\text { Adjusted } \\
\boldsymbol{R} \\
\text { squared }\end{array}$ \\
\hline 1 & $.903^{\mathrm{a}}$ & 0.815 & 0.814 \\
\hline
\end{tabular}

ship voyage time variable and distance variable against the amount of LSS tariff.

\subsection{Coefficient of Determination}

The coefficient of determination describes the proportion of the influence of all independent variables on dependent variables [48]. The value of the determinant coefficient can be measured by the $R$ squared value. The $R$ squared value in Table 8 is used to analyse the proportion of the influence of the entire independent variables on the dependent variable. As a rule, if the value of $R$ squared is near 1, then the influence of the independent variable is stronger. On the contrary, if the value of $R$ squared is closer to zero, the influence of the independent variable is getting weaker.

The table shows that the $R$ squared value is 0.815 , which is the squaring result of the R-value $(0.903)$. The $R$ squared value of 0.815 is equal to $81.5 \%$. This figure means that time and distance variables together affect the LSS tariff by $81.5 \%$, while the remaining $18.5 \%$ is influenced by other variables outside the regression equation whose variables are not studied.

Furthermore, an effective contribution calculation is used to identify the contribution of an independent variable's influence on dependent variables in regression [49]. Contribution can be calculated using the following formula:

$$
\begin{aligned}
& \text { Contribution }=\text { Regression Coefficient (Beta) } \\
& \text { Correlation Coefficient } \times 100 \%
\end{aligned}
$$

Contribution is calculated based on data such as $\mathrm{R}$ squared value (Table 8), correlation significance value (Table 9), and regression coefficient from Table 7. The three outputs are summarized in Table 10.

The contribution calculation for the time variable against the LSS tariff is as follows:

$$
\begin{gathered}
\text { Contribution }=\text { Regression Coefficient (Beta) } \times \\
\text { Correlation Coefficient } \times 100 \%
\end{gathered}
$$

Contribution Time $=-0.103 \times 0.479 \times 100 \%$

Contribution Time $=-4.93 \%$

The contribution calculation for distance variable against LSS tariff is as follows:

Contribution Distance $=0.962 \times 0.899 \times 100 \%$

Contribution Distance $=86.48 \%$

The contribution total is calculated below,

Contribution total $=-4.93 \%+86.48 \%$

Contribution total $=81.55 \%$

Based on these calculation results, we conclude that the shipping distance variable contributes predominantly to the determination of the amount

\begin{tabular}{|c|c|c|c|c|}
\hline & & $\begin{array}{c}\text { Correlations } \\
\text { Time }\end{array}$ & Distance & LSS \\
\hline \multirow[t]{2}{*}{ Time } & Pearson Correlation & 1 & $.605^{* *}$ & $479^{* *}$ \\
\hline & Sig. (2-tailed) & 37 & $\begin{array}{r}0 \\
370\end{array}$ & $\begin{array}{r}0 \\
370\end{array}$ \\
\hline \multirow[t]{2}{*}{ Distance } & Pearson Correlation & $.605^{* *}$ & 1 & $.899^{* *}$ \\
\hline & $\begin{array}{l}\text { Sig. (2-tailed) } \\
\mathrm{N}\end{array}$ & $\begin{array}{r}0 \\
370\end{array}$ & 370 & $\begin{array}{r}0 \\
370\end{array}$ \\
\hline \multirow[t]{2}{*}{ LSS } & Pearson Correlation & $.479^{* *}$ & $.899^{* *}$ & 1 \\
\hline & Sig. (2-tailed) & $\begin{array}{r}0 \\
370\end{array}$ & $\begin{array}{r}0 \\
270\end{array}$ & 37 \\
\hline
\end{tabular}
of LSS tariff because the distance variable contributes to $86.48 \%$.

Table 9. Correlation significance value

${ }^{* *}$ Correlation is significant at the 0.01 level (2-tailed).

Table 10. Summary data for contribution calculation

\begin{tabular}{lccc}
\hline Variable & Regression Coefficient (Beta) & Correlation Coefficient (r) & R squared \\
\hline Time & -0.103 & 0.479 & \multirow{2}{*}{0.815} \\
Distance & 0.962 & 0.899 & \\
\hline
\end{tabular}




\subsection{Multiple Linear Regression Model Interpretation}

Interpreting the regression coefficient includes two things, the sign and the magnitude of the coefficient. The sign indicates the direction of the relationship. A positive coefficient sign means if the independent variable increases, the dependent variable also tends to increase. On the contrary, the negative sign indicates the opposite effect. If the independent variable increases, the dependent decreases. The magnitude of the coefficient identifies the nominal slope of the regression equation.

The results of the multiple linear regression calculations that have been performed using the SPSS application, which has met all the classic assumptions tests and the model feasibility test, generates the following equation:

$$
\begin{aligned}
Y=\alpha+\beta_{1} X_{1} & +\beta_{2} X_{2}+\mathrm{e} \\
\mathrm{Y}=305,349.086 & -15,242.442 \text { Time } \\
& +886.212 \text { Distance }+0
\end{aligned}
$$

The constant value of the multiple linear regression equation is $305,349.086$, which means that if the value of the time and distance variable is 0 , then the resulting LSS tariff is Rp305,349.086. Furthermore, the regression coefficient for the time variable is $-15,242.442$, and the distance variable is 886.212 . The regression coefficient of time is negative, which shows a negative relationship with the LSS tariff. It means that if the ship voyage time increases, the LSS tariff decreases. On the other hand, if the ship voyage time decreases, the LSS tariff increases.

Further analysis is conducted to depict this negative relationship. In their research elements, Bialystocki and Konovessis find that fuel consumption depends on the voyage time and sea states [23]. If the ship travels at a higher speed, thus the arrival time will be early with a shorter voyage time. But this also consumes more fuel; thus, the fuel cost is higher. Another research by Utomo finds that as the ship engine's rpm increases to speed up the voyage, more fuel consumption is needed [50]. This negative relationship also corresponds to the ship efficiency strategy known as "slow steaming" to achieve the compounding effect: a ship runs at a slower speed to save fuel consumption but at the expense of longer travel time [51]. If we interpret these study results, higher fuel consumption will also generate higher fuel costs, which automatically will increase the LSS tariff. Therefore, a ship that travels in a shorter time requires more fuel, hence more fuel cost and, in the end, higher LSS rates. This research then concludes that $\mathrm{H} 1$ is rejected.

The positive relationship between distance regression coefficient and the LSS tariff explains that if the distance travelled by ship is getting farther, a higher LSS tariff results. Similarly, if the distance travelled by ship is shorter, then the LSS tariff will also be less expensive. Based on the results of multiple linear regressions, it can be interpreted that if there is an increase in the shipping distance by $1 \mathrm{NM}$ (Nautical Mile), then the LSS tariff will increase by Rp 886,212.00. At the same time, if the distance of the ship is reduced by 1 NM then the LSS tariff will increase by $\mathrm{Rp} 886,212.00$. This result also corresponds with research by Kim et al., who describes the equation of fuel efficiency, that sailing distance is directly proportional with fuel consumption [52]. It can be interpreted that the destination port distinguishes the need for fuel consumption because the farther the destination, the more fuel is needed, and a higher LSS tariff will be charged, and vice versa. Thus, this research concludes that $\mathrm{H} 2$ is accepted.

\subsection{Polynomial Regression}

Multiple regression includes a technique, namely polynomial regression [53]. In the context of this research, polynomial regression was implemented to prove that the ship voyage time and distance are independent variables that do not coincide and describe their relationship with the LSS tariff as the dependent variable. To further analyse the relationship between the dependent variable and its independent variables, this study developed a polynomial regression calculation to compare the main results from multiple linear regression. Polynomial regression was added because, compared to traditional regression, it may show greater explanatory as it provides nuanced views on the relationships between different combinations of independent variables and a dependent variable in three-dimensional space [31]. This non-linear analysis is used to investigate beyond simple relationships between two or more variables and further explain the variables' interaction influence [54].

Typically, polynomial regression is used when simple linear regression does not produce a fit model (the model corresponds to the original data distribution). A model that does not fit can be indicated that there is no significant influence between the dependent variable and the independent variable, so there is a possibility that the model is a polynomial function [55]. The 
polynomial model involves a hierarchical analysis of polynomial equations, which continues until higher order and is statistically significant [54]. The higher the order used to determine the model, the more fit the model with the original data. Still, it is necessary to avoid conditions where the model is too fit with the original data (overfitting). Overfitting needs to be avoided because this model is very unrealistic.

By using Microsoft Excel, the polynomial regression model was generated to the highest order of 6 . The models were compared to identify the fittest by comparing $R$ squared and Adjusted $R$ squared. An increasing $R$ squared near the value of 1.0 indicates that the data nearly perfectly fit the model [56]. Additionally, the p-value was also considered to determine that the regression coefficient of the model is significant.

Table 11. Polynomial regression result

\begin{tabular}{clccc}
\hline Order & Variables & $\begin{array}{c}\mathbf{R} \\
\text { squared }\end{array}$ & $\begin{array}{c}\text { Adjusted } \\
\mathbf{R} \\
\text { squared }\end{array}$ & $\begin{array}{c}\mathbf{p}- \\
\text { value }\end{array}$ \\
\hline \multirow{2}{*}{2} & Time & 0.3556 & 0.3539 & 0.000 \\
& Distance & 0.8095 & 0.8090 & 0.000 \\
3 & Time & 0.3801 & 0.3784 & 0.000 \\
& Distance & 0.8154 & 0.8149 & 0.000 \\
4 & Time & 0.4338 & 0.4323 & 0.000 \\
& Distance & 0.8612 & 0.8608 & 0.000 \\
5 & Time & 0.5488 & 0.5476 & 0.000 \\
& Distance & 0.8615 & 0.8612 & 0.000 \\
6 & Time & 0.5532 & 0.5520 & 0.000 \\
& Distance & 0.8976 & 0.8974 & 0.000 \\
\hline
\end{tabular}

Based on Table 11, the regression model from the $6^{\text {th }}$ order was chosen as the optimal model for the independent variable of ship voyage time. The regression model is as follows:

$$
\begin{aligned}
y= & -2175.9 x^{6}+60826 x^{5}-657058 x^{4}+ \\
& 3^{6} x^{3}-9^{6} x^{2}+1^{7} x-5^{6}
\end{aligned}
$$

The $6^{\text {th }}$ order has the highest value of $R$ squared of 0.5532 , representing that $55.32 \%$ of the variation in the LSS tariff is explained by the ship voyage time. The adjusted $R$ squared only differs a little at 0.5520 . The table also illustrates that ship voyage time is statistically significant in influencing the amount of LSS tariff.

Moreover, Table 10 also generates the best fit for regression model of ship voyage distance independent variable, taken from the $6^{\text {th }}$ order with the equation result as follows:

$$
\begin{aligned}
y= & 5^{-10} x^{6}-2^{-6} x^{5}+0.0038 x^{4}- \\
& 3.2734 x^{3}+1517.7 x^{2}- \\
& 351197 x+3^{7}
\end{aligned}
$$

The highest $R$ squared value of 0.8976 and adjusted $R$ squared value of 0.8974 represent that around $89 \%$ of the amount of LSS tariff is influenced by the ship voyage distance, with the $p$ value of 0.000 . It means that the ship distance variable dominantly and significantly influences the LSS tariff.

Furthermore, we take some examples from the polynomial data. If the ship voyage time is spent to 4 days, the generated LSS tariff is Rp1,182,222. This number is very close to the actual data of Rp1,200,000 for 4 days ship voyage time. If the voyage time is increased to 5 and 6 days, the LSS tariff will decrease to $R p 1,169,231$ and Rp864,516, respectively. This trend corresponds to the previous result from the multiple linear regression, which states a negative relationship between ship voyage time and the LSS tariff.

Other examples from the distance variable are also taken into account. The LSS tariff generated for a short voyage distance of $360 \mathrm{NM}$ is Rp474,337. For the medium distance of 790 NM and long distance $1117 \mathrm{NM}$, the LSS tariff amounts are Rp828,135 and Rp1,206,351, respectively. These numbers indicate that, unlike the time variable result, the polynomial regression for the distance variable shows a positive relationship with the LSS tariff. This result also suggests that both the multiple linear regression (as the primary method in this research) and polynomial regression successfully revealed similar relationships between the dependent and independent variables.

\section{CONCLUSION}

The study result shows that both ship voyage time and distance simultaneously affect the determinants of the LSS tariff. From the result of this primary research method (multiple linear regression), the magnitude of the influence of both variables is $81.5 \%$. The rest of the effect of other variables was not studied and beyond the limitations of this study. Variable of shipping distance contributes dominantly to determine the LSS amount, with the contribution value of $86.48 \%$. It also shows a positive relationship with the LSS tariff, where a longer shipping distance means a higher tariff and vice versa. On the other hand, ship voyage time does not strongly influence the tariff as the distance variable, shown 
by the contribution value of $-4.93 \%$. Additionally, there is a negative relationship between the duration of ship voyages with the LSS tariff, which means a longer voyage duration will likely result in a less expensive LSS tariff, and vice versa. However, this relationship is not quite strong, meaning that other factors need to be considered to get more valid results. Finally, the polynomial regression also describes the similar relationships between the variables: the ship voyage distance dominantly influences the LSS tariff with a positive relationship. For future research, other parameters such as weather conditions and shiploads can also be considered.

\section{REFERENCES}

[1] Editor. (7 February, 2020) Advantages of Maritime Transport. Blue Ocean Magazine. Available at: https://blueoceanmag.com/advantagesof-maritime-shipping/

[2] R. Rumaji and A. Adiliya, "Port maritime connectivity in South-East Indonesia: A new strategic positioning for transhipment port of Tenau Kupang," The Asian Journal of Shipping Logistics, vol. 35, no. 4, pp. 172-180, 2019. Available at: https://doi.org/10.1016/j.ajsl.2019.12.004

[3] J. G. Speight, Environmental Analysis and Technology for the Refining Industry. Wiley, 2005. Available at: https://books.google.co.id/books?id=UM4 cQUj7g6QC

[4] IMO. (2020). IMO 2020 - cutting sulphur oxide emissions Available at: https://www.imo.org/en/MediaCentre/Hot Topics/Pages/Sulphur-2020.aspx Accessed on: 28 April, 2021.

[5] Surat Edaran Tentang Kewajiban Penggunaan Bahan Bakar Low Sulfur dan Larangan Mengangkut atau Membawa Bahan Bakar yang Tidak Memenuhi Persyaratan serta Pengelolaan Limbah Hasil Resirkulasi Gas Buang dari Kapal Kementerian Perhubungan Surat Edaran No. 35 Tahun 2019, Available at: https://idih.dephub.go.id/assets/uudocs/s eEI/2019/SE 35 TAHUN 2019 TENTA NG KEWAJIBAN PENGGUNAAN BAH AN BAKAR LOW SULFUR DAN LAR ANGAN MENGANGKUT ATAU MEMB AWA BAHAN BAKAR.pdf.
[6] D. Huang et al., "Lifespan cost analysis of alternatives to global sulphur emission limit with uncertainties," Journal of Engineering for the Maritime Environment, vol. 00, no. Special Issue Article, 2020. Available at: https://doi.org/10.1177/14750902209831 40

[7] Shapiro. (2020). Low Sulfur Surcharge: High Confusion and High Costs. Available at: https://www.shapiro.com/low-sulfursurcharge-high-confusion-and-highcosts/Accessed on: 5 July, 2021.

H. Manaadiar. (14 December 2018). What is Low Sulphur Surcharge and why is it applicable..?? Available at: https://www.shippingandfreightresource.c om/what-is-low-sulphur-surcharge-andwhy-is-it-applicable/ Accessed on: 5 July, 2021.

[9] T. Notteboom, "The impact of low sulphur fuel requirements in shipping on the competitiveness of roro shipping in Northern Europe," WMU Journal of Maritime Affairs, vol. 10, no. 1, pp. 63-95, 2011/04/01 2011. Available at: https://link.springer.com/article/10.1007\% 2Fs13437-010-0001-7

[10] U. Shuaibu, "The economic impact of low sulphur compliance on future fuel cost and container freight rates: a case study of Shanghai-Lagos," Master of Science, Shipping Management and Logistics, World Maritime University, 2019,Available at:

https://commons.wmu.se/all dissertation s/1121?utm source=commons.wmu.se\% 2Fall dissertations\%2F1121\&utm mediu m=PDF\&utm campaign=PDFCoverPage $\underline{s}$.

[11] S. Rahm, "The costly future of green shipping," in "Schroders," 2015, Available at:

https://www.schroders.com/pl/sysglobala ssets/digital/insights/pdfs/the-costlyfuture-of-green-shipping-schroders.pdf.

[12] C. Sys et al., "International emission regulation in sea transport: Economic feasibility and impact," Transportation Research Part D: Transport and Environment, vol. 45, pp. 139-151, 2016. 
Available at: https://doi.org/10.1016/j.trd.2015.06.009

[13] P.-C. Wu and C.-Y. Lin, "Cost-Benefit Evaluation on Promising Strategies in Compliance with Low Sulfur Policy of IMO," Journal of Marine Science and Engineering, vol. 9, no. 1, p. 3, 2021. Available at: https://doi.org/10.3390/jmse9010003

[14] M. M. Golias et al., "The berth allocation problem: Optimizing vessel arrival time," Maritime Economics \& Logistics, vol. 11, no. 4, pp. 358-377, 2009/12/01 2009. Available at: https://doi.org/10.1057/mel.2009.12

[15] E. Bal Beşikçi et al., "An artificial neural network based decision support system for energy efficient ship operations," Computers \& Operations Research, vol. 66, pp. 393-401, 2016/02/01/ 2016. Available at: https://doi.org/10.1016/i.cor.2015.04.004

[16] ShipHub. (2021). LSF/LSS in Sea Freight. Available at: https://www.shiphub.co/lsfIss-in-sea-freight/ Accessed on: August 5, 2021.

[17] A. Kerriou. (February 10, 2020). "Low Sulfur" Regulations: the Impact on Maritime Shipping Prices. Available at: https://market-insights.upply.com/en/lowsulfur-regulations-the-impact-onmaritime-shipping-prices Accessed on: August 4, 2021.

[18] N. H. Said. (15 January 2020). Bikin Biaya Logistik Membengkak, Asosiasi Perusahaan Logistik Tolak LSS. Available at:

https://rakyatku.com/read/176515/bikinbiaya-logistik-membengkak-asosiasiperusahaan-logistik-tolak-Iss Accessed on: 5 July, 2021.

[19] Editor. (January 13, 2020). Dampak IMO 2020, Tarif Angkut Kontainer Domestik Melonjak Available at: https://jurnalmaritim.com/dampak-imo2020-tarif-angkut-kontainer-domestikmelonjak/ Accessed on: August 24, 2020.

[20] D. Sudrajat, "Segmentasi pasar penyedia jasa logistik (third party logistics) di Indonesia," Binus Business Review, vol.
1, no. 2, pp. 332-341, 2010. Available at: https://doi.org/10.21512/bbr.v1i2.1079

[21] T. Prasetya. (2017, 22 September). Tren positif sektor freight forwading di Indonesia. Available at: https://industri.kontan.co.id/news/trenpositif-sektor-freight-forwading-diindonesia

[22] R. M. Azka. (2020, 19 July ). Aturan Ini Tumpang Tindih, Freight Forwarder Geleng Kepala. Available at: https://ekonomi.bisnis.com/read/2020071 9/98/1268133/aturan-ini-tumpang-tindihfreight-forwarder-geleng-kepala

[23] N. Bialystocki and D. Konovessis, "On the estimation of ship's fuel consumption and speed curve: A statistical approach," Journal of Ocean Engineering Science, vol. 1, no. 2, pp. 157-166, 2016. Available at:

https://doi.org/10.1016/i.joes.2016.02.00 1

[24] L. Bui-Duy and N. Vu-Thi-Minh, "Utilization of a deep learning-based fuel consumption model in choosing a liner shipping route for container ships in Asia," The Asian Journal of Shipping and Logistics, vol. 37, no. 1, pp. 1-11, 2021/03/01/ 2021. Available at: https://doi.org/10.1016/j.ajsl.2020.04.003

[25] H. Andersson et al., "Integrated maritime fleet deployment and speed optimization: Case study from RoRo shipping," Computers \& Operations Research, vol. 55, pp. 233-240, 2015/03/01/ 2015. Available at: https://doi.org/10.1016/j.cor.2014.03.017

[26] T. P. V. Zis et al., "Policy measures to avert possible modal shifts caused by sulphur regulation in the European Ro-Ro sector," Transportation Research Part D: Transport and Environment, vol. 70, pp. 117, 2019/05/01/ 2019. Available at: https://doi.org/10.1016/j.trd.2019.03.001

[27] CNC. (January 28, 2021). Intra-Asia Market: Low Sulphur Surcharge (LSS) Update for March 2021. Available at: https://www.cnc-

ebusiness.com/news/113/intra-asiamarket-low-sulphur-surcharge-lss- 
update-for-march-2021 Accessed on: August 5, 2021.

[28] Maersk. (July 2, 2019). Rate Announcements: Scope Far East Asia to Mediterranean. Available at: https://www.maersk.com/news/articles/20 19/07/02/ra-scope-far-east-asiamediterranean Accessed on: August 5, 2021.

[29] Bacargo. (2019). Informasi Biaya Low Sulfur Surcharge (LSS). Available at: https://bahteraandalan.com/blog/informa si-biaya-low-sulfur-surcharge.html Accessed on: August 5, 2021.

[30] M. Kasiram, Metodologi penelitian kuantitatif dan kualitatif (Malang: UINMalang Pers). 2008. Available at: http://repository.uin-malang.ac.id/1621/

[31] L. R. Shanock et al., "Polynomial Regression with Response Surface Analysis: A Powerful Approach for Examining Moderation and Overcoming Limitations of Difference Scores," Journal of Business and Psychology, vol. 25, no. 4, pp. 543-554, 2010/12/01 2010. Available at: https://doi.org/10.1007/s10869-010$\underline{9183-4}$

[32] K.-h. Lai et al., "Are trade and transport logistics activities mutually reinforcing? Some empirical evidences from ASEAN countries," Journal of Shipping and Trade, vol. 4, no. 1, p. 2, 2019/04/26 2019. Available at: https://10.1186/s41072-019$\underline{0041-x}$

[33] N. Pandis, "Multiple linear regression analysis," American Journal of Orthodontics and Dentofacial Orthopedics, vol. 149, no. 4, p. 581, 2016/04/01/ 2016. Available at: https://doi.org/10.1016/j.ajodo.2016.01.0 $\underline{12}$

[34] Y. Wibisono, Metode Statistik, 1 ed. Yogyakarta: Gadjah Mada University Press, 2005. Available at: http://ugmpress.ugm.ac.id/en/product/ars itektur/metode-statistik

[35] S. Aisyah and K. Kuswantoro, "Pengaruh Pendapatan, Harga Dan Nilai Tukar Negara Mitra Dagang Terhadap Ekspor
Crude Palm Oil (CPO) Indonesia," Jurnal Ekonomi-Qu, vol. 7, no. 1, 2017. Available at:

http://dx.doi.org/10.35448/jequ.v7i1.4221

[36] L. M. Wulandari and S. Zuhri, "Pengaruh Perdagangan Internasional Terhadap Pertumbuhan Ekonomi Indonesia Tahun 2007-2017," Jurnal REP (Riset Ekonomi Pembangunan), vol. 4, no. 2, pp. 119-127, 2019. Available at: http://dx.doi.org/10.31002/rep.v4i2.781

[37] R. Permanasari, "Pengaruh Motivasi dan Lingkungan Kerja Terhadap Kinerja PT. Augrah Raharjo Semarang," Management Analysis Journal, vol. 2, no. 2, 2013. Available at: https://doi.org/10.15294/maj.v2i2.2493

[38] M. Anshori, Metodologi Penelitian Kuantitatif : Edisi 1. Airlangga University Press, 2019. Available at: https://books.google.co.id/books?id=ltq0 DwAAQBAJ

[39] G. Norman, "Likert scales, levels of measurement and the "laws" of statistics," Advances in Health Sciences Education, vol. 15, no. 5, pp. 625-632, 2010/12/01 $2010 . \quad$ Available at: https://10.1007/s10459-010-9222-y

[40] J. R. Evans and W. M. Lindsay, An Introduction to Six Sigma and Process Improvement. Cengage Learning, 2014. Available https://books.google.co.id/books?id=CYH AAgAAQBAJ

[41] T. K. Kim and J. H. Park, "More about the basic assumptions of t-test: normality and sample size," (in eng), Korean journal of anesthesiology, vol. 72, no. 4, pp. 331335, 2019. Available at: https://10.4097/kja.d.18.00292

[42] I. Ghozali, Aplikasi analisis multivariate dengan program SPSS. Badan Penerbit Universitas Diponegoro, 2006. Available at:

https://books.google.co.id/books?id=JdqJ AQAACAAJ

[43] D. N. A. Janie, Statistik deskriptif \& regresi linier berganda dengan SPSS. Semarang University Press, 2012. Available at: https://repository.usm.ac.id/files/bookusm 
/B208/20170519022209-StatistikDeskriptif-\%26-Regresi-Linier-Bergandadengan-SPSS.pdf

[44] A. Marzuki et al., Praktikum Statistik. Ahli Media Press, 2020. Available at: https://books.google.co.id/books?id=kOEAAAQBAJ

[45] M. Nisfiannoor, Pendekatan statististika Modern untuk IImu Sosial. Penerbit Salemba. Available at: https://books.google.co.id/books?id=1j O 7aHTZD8C

[46] I. Gani and S. Amalia, Alat Analisis Data: Aplikasi Statistik untuk Penelitian Bidang Ekonomi dan Sosial. Penerbit Andi. Available at: https://books.google.co.id/books?id=1FSi CgAAQBAJ

[47] Dr Muhammad Yusuf and D. M. Nastiti, Analisis Data Penelitian : Teori \& Aplikasi dalam Bidang Perikanan. PT Penerbit IPB Press, 2019. Available at: https://books.google.co.id/books?id=qrkR EAAAQBAJ

[48] D. Siagian, Metode statistika untuk bisnis dan ekonomi. Gramedia Pustaka Utama, $2000 . \quad$ Available at: https://books.google.co.id/books?id=saZ ED8D4mpsC

[49] S. Hadi, Analisis Regresi. Penerbit Andi. Available https://books.google.co.id/books?id=Byz Bslce0zsC

[50] B. Utomo, "Hubungan Antara Konsumsi Bahan Bakar dengan Berbagai Perubahan Kecepatan pada Motor Diesel Penggerak Kapal," Jurnal Rekayasa Mesin, vol. 15, no. 2, pp. 163-170, 2020. Available at: http://dx.doi.org/10.32497/jrm.v15i2.1957

[51] J. P. Rodrigue, The Geography of Transport Systems. Taylor \& Francis, 2020. Available at: https://books.google.co.id/books?id=EGl PEAAAQBAJ

[52] Y.-R. Kim et al., "Development of a Fuel Consumption Prediction Model Based on Machine Learning Using Ship In-Service
Data," Journal of Marine Science Engineering, vol. 9, no. 2, p. 137, 2021. Available at: https://doi.org/10.3390/imse9020137

[53] E. Ostertagova, "Modelling Using Polynomial Regression," Procedia Engineering, vol. 48, pp. 500-506, 12/31 2012. Available at: https://doi.org/10.1016/j.proeng.2012.09. $\underline{545}$

[54] S. Darshana and A. Maura, "Polynomial Regression and Response Surface Methodology: Theoretical Non-Linearity, Tutorial and Applications for Information Systems Research," Australasian Journal of Information Systems, vol. 23, no. 0, 09/23 2019. Available at: https://doi.org/10.3127/ajis.v23i0.1966

[55] J. S. Malensang et al., "Pengembangan Model Regresi Polinomial Berganda pada Kasus Data Pemasaran," Jurnal IImiah Sains, vol. 12, no. 2, pp. 149-152, 2013. Available https://doi.org/10.35799/jis.12.2.2012.74 $\underline{0}$

[56] D. F. Hamilton et al., "Interpreting regression models in clinical outcome studies," (in eng), Bone \& joint research, vol. 4, no. 9, pp. 152-153, 2015. Available at: $\quad$ https://doi.org/10.1302/20463758.49 .2000571

\section{Authors Biography}

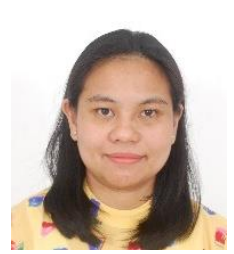

$$
\begin{aligned}
& \text { Gita Kurnia } \\
& \text { Lecturer in Logistics } \\
& \text { Engineering Undergraduate } \\
& \text { Study Program, Universitas } \\
& \text { Pertamina. Research focus is } \\
& \text { maritime logistics. }
\end{aligned}
$$

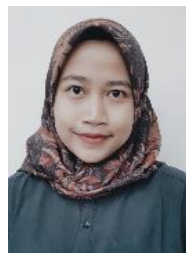

